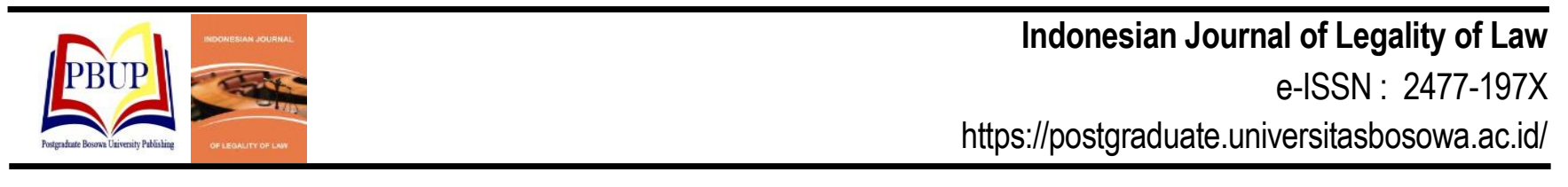

\title{
EFEKTIVITAS PELAKSANAAN PENGAWASAN OTORITAS JASA KEUANGAN TERHADAP PERBANKAN DI KOTA MAKASSAR
}

\author{
The Supervision Effectiveness of Otoritas Jasa Keuangan towards Banking Financial Institutions in \\ Makassar City
}

\author{
Muhammad Saleh ${ }^{1}$, Andi Muh. Arfah Pattenreng ${ }^{2}$, Abdul Haris Hamid ${ }^{2}$ \\ ${ }^{1}$ Otoritas Jasa Keuangan Makassar \\ ${ }^{2}$ Program Studi Ilmu Hukum Program Pascasarjana Universitas Bosowa \\ Email: alhezaleh@gmail.com
}

Diterima: 10 Januari 2021/Disetujui: 01 Juni 2021

\begin{abstract}
ABSTRAK
Otoritas Jasa Keuangan merupakan lembaga yang independen dan bebas dari campur tangan pihak lain, dibentuk dengan salah satu tujuan yaitu untuk mengawasi lembaga keuangan. Pengawasan OJK dilakukan agar lembaga keuangan yang diawasi tidak melakukan pelanggaran dan terus berkembang serta tidak merugikan masyarakat. Penelitian ini bertujuan untuk mengetahui pelaksanaan tugas pokok Otoritas Jasa Keuangan di Kota Makassar dalam pengawasan aktifitas perbankan, meliputi kelembagaan bank, kesehatan bank dan aspek kehati-hatian bank. Penelitian ini dilaksanakan di Kota Makassar pada Kantor Otoritas Jasa Keuangan Regional 6 Sulawesi Maluku Papua (SULAMPUA) Kota Makassar. Metode yang digunakan adalah pendekatan normatif empiris. Maksudnya pendekatan yang dilakukan untuk menganalisa tentang sejauh manakah suatu peraturan atau perundang-undangan atau hukum yang sedang berlaku secara efektif kepada publik mengenai peranan Otoritas Jasa Keuangan. Hasil penelitian ini menunjukkan bahwa pelaksanaan pengawasan oleh Otoritas Jasa Keuangan sangat penting dalam pengawasan aktivitas perbankan yang meliputi kegiatan usaha, tingkat kepatuhan, serta hal yang berdampak kepada masyarakat terkait krisis integritas sebuah lembaga keuangan.
\end{abstract}

Kata Kunci : OJK, Pengawasan Sistem Terintegrasi, Lembaga Keuangan Perbankan

\begin{abstract}
Financial Services Authority (OJK) is an independent institution and free form other parties' interference, which was formed with one of the objectives of a joint financial institution. OJK supervision is carried out so that the supervised financial institutions do not commit violations and continue to develop as well as do not harm the public. This study aims to see the implementation of the main duties of the financial services authority in Makassar City in monitoring banking activities which include aspects of banking, bank health and banking prudence. This research was conducted in Makassar City at the Regional Financial Services Authority Office 6 Sulawesi Maluku Papua (SULAMPUA) Makassar City. The method used is empirical normative approach. This means that the approach is to analyze the extent to which a regulation or statute is appropriate and effective for the public regarding the roles of Financial Services Authority. The results showed that the implementation of supervision by the Financial Services Authority is very important in the supervision of banking activities, including business activities, the level of supervision, as well as matters that have an impact on society related to the integrity of a financial institution.
\end{abstract}

Keywords: OJK, Integrated Supervision System, Financial Banking Institution

\section{PENDAHULUAN}

Terbentuknya Otoritas Jasa Keuangan (OJK) dilatarbelakangi oleh adanya kebutuhan untuk melakukan penataan kembali lembaga-lembaga yang melaksanakan pengawasan disektor jasa keuangan. Hal tersebut dilandasi oleh beberapa hal, yaitu Amanat Undang-Undang Dasar 1945, Perkembangan Industri Keuangan, Konglomerasi Lembaga Jasa Keuangan, dan Perlindungan Keuangan. Pengalihan pengawasan perbankan setelah dibentuknya
Undang-Undang OJK ini dimaksudkan untuk memisahkan pengawasan perbankan dari bank sentral ke sebuah badan atau lembaga yang independen di luar bank sentral.

Dasar hukum pemisahan pengawasan tersebut yaitu Pasal 34 Undang-Undang Nomor 3 Tahun 2004 tentang Perubahan atas Undang-Undang Nomor 23 Tahun 1999 tentang Bank Indonesia yang menyatakan bahwa "Tugas mengawasi Bank akan dilakukan oleh lembaga pengawasan sektor jasa keuangan yang independen, dan dibentuk dengan undang-undang." Sedangkan pengawasan yang 
dilakukan yaitu terhadap bank dan perusahaan-perusahaan sektor jasa keuangan lainnya yang meliputi asuransi, dana pensiun, sekuritas, modal ventura, dan perusahaan pembiayaan, serta badan-badan lain yang menyelenggarakan pengelolaan dana masyarakat (Andika, 2010).

Latar belakang pembentukan OJK dikarenakan perlunya suatu lembaga pengawasan yang mampu berfungsi sebagai pengawas yang mempunyai otoritas terhadap seluruh lembaga keuangan, dimana lembaga pengawas tersebut bertanggung jawab terhadap kegiatan usaha yang dilakukan oleh bank maupun lembaga keuangan non-bank, sehingga tidak ada lagi lempar tanggung jawab terhadap pengawasannya.

Selain itu, kegiatan usaha yang dilakukan berakibat semakin besarnya pengaturan pengawasannya. Sehingga perlu adanya suatu alternatif untuk menjadikan pengaturan dan pengawasan maupun lembaga keuangan lainnya dalam satu atap. Hal ini mengingat tujuan dari pengaturan dan pengawasan perbankan adalah menciptakan sistem perbankan yang sehat, yang memenuhi tiga aspek, yaitu perbankan yang dapat memelihara kepentingan masyarakat dengan baik, berkembang secara wajar, dalam arti disatu pihak memperhatikan faktor risiko seperti kemampuan, baik dari sistem, finansial, maupun sumber daya manusia (Hermansyah, 2011).

Berdasarkan uraian latar belakang masalah tersebut, maka permasalahan dalam penelitian ini, meliputi: (1) Bagaimanakah pelaksanaan pengawasan yang dilakukan oleh Otoritas Jasa Keuangan (OJK) terhadap lembaga keuangan perbankan di Kota Makassar ?, (2) Bagaimanakah hambatan yang dihadapi oleh Otoritas Jasa Keuangan (OJK) dalam melaksanakan pengawasan aktivitas perbankan?

\section{METODE}

Tipe penelitian ini adalah penelitian deskriptif dengan pendekatan yuridis-empiris atau pendekatan tipe normatif dan empiris. Sedangkan sifat dari penelitian ini adalah deskriptif dan preskriptif (apa yang seharusnya). Penelitian ini dilaksanakan di Kabupaten Wajo yaitu tepatnya di Polres Wajo.

Populasi dalam penelitian ini, antara lain: seluruh warga desa di Wilayah Polres Wajo. Sampel dalam penelitian ini ditentukan sebanyak 50 orang responden dengan menggunakan teknik purposive sampling atau secara sengaja karena dapat memberikan keterangan dan informasi yang jelas tentang penegakan hukum terhadap penyalahgunaan dana desa oleh kepala desa di Wilayah Polres Wajo. Jenis data yang diperlukan dalam penelitian ini adalah data primer dan data sekunder. Metode pengumpulan data yang digunakan adalah melalui wawancara, dokumentasi dan kuesioner (angket).

Analisis data menggunakan metode analisis kualitatif dan kuantitatif, sebagai berikut:

1. Analisis data kualitatif dilakukan terhadap data yang tidak dapat dikuantifikasikan, seperti: bahan pustaka, hasil wawancara, dan peraturan perundang-undangan yang berhubungan dengan masalah yang dikaji.

2. Analisis data kuantitatif dilakukan terhadap data yang dikuantifikasikan dan akan dianalisis melalui tabel distribusi frekuensi untuk dijadikan bahan pengambilan kesimpulan dengan rumus (Soejono Soekanto, 2011) sebagai berikut:

$$
P=\frac{f}{n} x 100 \%
$$

Keterangan:

$$
\begin{array}{ll}
P & =\text { Persentase } \\
f & =\text { Frekuensi (nilai yang diperoleh) } \\
n & =\text { Jumlah responden (jumlah seluruh nilai) } \\
100 \% & =\text { Angka pembulat. }
\end{array}
$$

\section{HASIL DAN PEMBAHASAN}

3.1. Pelaksanaan Pengawasan yang Dilakukan oleh Otoritas Jasa Keuangan Terhadap Lembaga Keuangan Perbankan di Kota Makassar.

Pelaksanaan tugas pengawasan perbankan Itu dilaksanakan oleh Kepala Eksekutif beserta Deputi Komisioner Pengawas Perbankan IV Kantor Regional OJK, berdasarkan hasil wawancara pada tanggal 29 Januari 2020 dengan Ibu Nurfiaminah selaku Staff Pengawas Perbankan Regional 6 SULAMPUA, OJK dalam melaksanakan tugas pengawasan perbankan terhadap kegiatan jasa keuangan di sektor perbankan. Untuk melaksanakan tugas pengawasan OJK mempunyai wewenang pengaturan dan pengawasan mengenai kelembagaan bank, kesehatan bank, aspek kehatihatian serta pemeriksaan bank.

Bentuk pelaksanaan pengawasan yang dilakukan Otoritas Jasa Keuangan (OJK) terhadap seluruh kegiatan jasa keuangan perbankan adalah melakukan pengawasan secara terpadu dan OJK sendiri dapat melakukan pelayanan perlindungan hukum terhadap konsumen dalam hal kegiatan keuangan di Indonesia. Dampak yang ditimbulkan pasca pengalihan fungsi pengawasan perbankan dari Bank Indonesia kepada Otoritas Jasa Keuangan juga berjalan lebih efektif dan optimal dan sejauh ini sesuai dengan amanat yang tertuang dalam Undang-Undang No 21 tahun 2011 tentang Otoritas Jasa Keuangan yang tertuang pada Pasal 7.

\section{a. Pengawasan Bank Secara Langsung (On Site Supervision)}

Pengawasan bank secara langsung dapat dikatakan sebagai pengawasan khusus, meskipun dalam perkembangannya masih terdapat bank yang dinilai mengalami kesulitan dan dapat membahayakan kelangsungan usahanya dan sistem perbankan nasional. Agar sistem perbankan yang sehat dapat tercipta secara efektif, diperlukan pengawasan secara intensif berkala dalam hal penetapan kriteria bank yang jelas transparansi dalam memberikan informasi maupun data mengenai tingkat kesulitan Bank dalam kegiatan usahanya (meliputi penyaluran kredit dll).

Pembentukan Badan Penyehatan Perbankan Nasional (BPPN) merupakan langkah-langkah awal sebagai upaya dalam rangka menerapkan pelaksanaan restrukturisasi perbankan nasional, memberi perlindungan sedini mungkin terhadap adanya kualitas bank yang tidak sehat serta melakukan langkah-langkah penyelesaian kesulitan oleh faktor internal maupun eksternal. Langkah-langkah koordinasi antara BPPN dengan Bank Indonesia dalam rangka restrukturisasi perbankan nasional antara lain dituangkan dalam kesepakatan bersama antara Gubernur BI dan Ketua BPPN.

Adapun kewenangan pengawasan dan pengaturan bank oleh OJK meliputi: 
1. Pemeriksaan umum dan khusus dengan tujuan untuk mendapatkan gambaran keadaan keuangan bank dan untuk memantau tingkat kepatuhan bank terhadap peraturan yang berlaku serta untuk mengetahui apakah terdapat praktik-praktik tidak sehat yang membahayakan kelangsungan usaha bank;

2. Kewenangan untuk menetapkan tatacara perizinan dan pendirian suatu bank, meliputi pemberian izin dan pencabutan izin usaha bank, pemberian izin pembukuan, penutupan, pemindahan kantor bank, pemberian persetujuan atas kepemilikan dan kepengurusan bank, pemberian izin kepada bank untuk menjalankan kegiatan-kegiatan usaha tertentu.

3. Kewenangan untuk menetapkan ketentuan yang menyangkut aspek usaha dan kegiatan perbankan dalam rangka menciptakan perbankan sehat guna memenuhi jasa perbankan yang diinginkan masyarakat.

Dalam menghadapi pesatnya perkembangan lingkungan eksternal dan internal bisnis perbankan, Bank harus mampu beradaptasi agar dapat menghadapi risiko yang berkaitan erat dengan fungsinya sebagai lembaga intermediasi. Bank diharapkan dapat menerapkan manajemen risiko. Melalui penerapan manajemen risiko, Bank diharapkan dapat mengukur dan mengendalikan risiko yang dihadapi dalam melakukan kegiatan usahanya.

Bank dituntut pula untuk mengantisipasi kebutuhan infrastruktur Teknologi Informasi (TI) yang memadai dalam rangka menghadapi implementasi kerangka Basel (Basel framework). Mengingat penyelenggaraan TI dapat menimbulkan berbagai risiko dan untuk melindungi kepentingan Bank dan juga nasabah, Bank dituntut untuk menerapkan manajemen risiko secara efektif sehingga Bank dapat melakukan pengendalian dari kemungkinan penambahan risiko yang terjadi.

Dapat dilihat bahwa pengawasan langsung merupakan bagian dari program peningkatan fungsi dalam menciptakan industri perbankan yang kuat dan memiliki ketahanan dalam menghadapi resiko, hal ini terwujud seiring dengan pengembangan pengawasan yang berbasis resiko.

\section{b. Pengawasan Bank Secara Tidak Langsung (Off Site Supervision)}

Pengawasan bank secara tidak langsung merupakan bentuk pengawasan yang dilakukan terhadap bank baik secara individual maupun kelompok/konglomerasi dengan cara menelaah laporan-laporan yang disampaikan secara rutin oleh Bank dengan tujuan untuk menilai kepatuhan bank terhadap peraturan-peraturan yang telah ditetapkan oleh otoritas serta pemantauan secara berkala agar pelaksanaan operasional bank berjalan sesuai dengan peraturan/kebijakan yang berlaku. Secara umum dapat dikatakan bahwa tujuan dilaksanakannya pengawasan adalah aktifnya fungsi kontrol pengelolaan agar :

1. Tujuan perusahaan tercapai, artinya jika semua aktivitas perusahaan (perbankan) berjalan sesuai dengan yang direncanakan maka pencapaian target akan mudah tercapai (laba perusahaan meningkat);

2. Memudahkan pencegahan, artinya jika ada indikasi atau gejala akan adanya penyimpangan, maka mudah untuk ambil tindakan pencegahan nyata;

3. Mengurangi nilai karyawan untuk melakukan penyimpangan, dengan cara membuat seseorang menjadi bekerja dengan baik, karena merasa ada pengawasan terhadap aktivitas;
4. Pengendalian biaya, artinya dengan adanya pengelolaan dan pengawasan maka biaya yang tidak perlu keluar dapat diminimalkan segala bentuk kebocoran.

Sistem Informasi Perbankan (SIP) adalah sistem informasi yang digunakan Pengawas bank untuk melakukan kegiatan analisis terhadap kondisi bank dan melakukan penilaian Tingkat Kesehatan (TKS) Bank dengan menggunakan pendekatan risiko (Risk Based Bank Rating/RBBR), mempercepat diperolehnya informasi kondisi keuangan bank.

Dari uraian tentang pengawasan diatas, penulis menilai bahwa OJK hadir dalam mewujudkan industri jasa keuangan sebagai pilar perekonomian nasional yang berdaya saing global, dengan menginginkan jasa keuangan yang dijalankan oleh lembaga Keuangan Perbankan dapat memberikan manfaat yang yang sebesar-besarnya untuk kepentingan masyarakat dalam ikut serta memajukan kesejahteraan umum melalui sistem pengawasan yang memenuhi standar operasional.

\section{c. Tindakan Represif yang Dilakukan oleh OJK}

Pengawas Perbankan OJK Makassar pada tanggal 7 April 2020, beliau menjelaskan bahwa tindakan represif yang dilakukan oleh OJK apabila terjadi pelanggaran yang dilakukan oleh perbankan mulai dari pelanggaran ringan maupun pelanggaran berat sebagaimana telah diatur dalam setiap kebijakan/peraturan yang diterbitkan oleh OJK, maka atas setiap pelanggaran ketentuan yang dilakukan oleh perbankan dapat dikenakan sanksi baik berupa peringatan tertulis, denda, penurunan tingkat kesehatan, pembatasan produk dan aktivitas bank, pemberhentian pengurus bank sampai pada pencabutan izin usaha.

3.2 Hambatan yang Dihadapi oleh OJK dalam Melaksanakan Pengawasan Aktivitas Perbankan

Hambatan atau rintangan yang sering dihadapi oleh OJK dalam melaksanakan Pengawasan diantaranya :

1. Terdapat ketimpangan antara jumlah pengawas dan jumlah industri perbankan yang diawasi sehingga hal tersebut dapat berdampak pada kurang optimalnya pelaksanaan pengawasan.

2. Dewasa ini, perbankan di Indonesia telah mulai bergerak kearah digital banking, hal tersebut menjadi tantangan tersendiri bagi OJK dalam pengawasannya mengingat hal tersebut merupakan hal yang baru dan OJK wajib membuat aturan/kebijakan yang betul-betul dapat diimplementasikan dengan baik kepada semua industri perbankan.

3. Beragamnya produk dan aktivitas bank baik yang telah berjalan atau yang akan diterbitkan oleh industri perbankan menjadikan OJK sebagai regulator harus bergerak lebih cepat dalam hal pengaturan, pembuatan kebijakan dan perizinannya.

Dalam hal melakukan fungsi kontrol pengawasan perbankan OJK telah membangun sistem pelaporan perbankan untuk mempermudah tugas pengawasan bank diantaranya seperti APOLO, SIPENA, SLIK, DLL. Agar sistem tersebut dapat terus diandalkan, OJK akan terus mengembankan dan menyesuaikan sistem yang ada sesuai kebutuhan dan perkembangan teknologi.

Hambatan lain yang dihadapi oleh OJK adalah Indonesia memiliki komitmen yang tinggi dalam proses membentuk OJK untuk dapat melaksanakan tugas dalam skala ekonomi yang lebih besar, reformasi hukum, dan politik yang lebih baik. 
Penulis melihat bahwa dalam hal pengawasan aktivitas perbankan faktor yang menjadi penghambat adalah ketika tertutupnya informasi tentang pelaksanaan teknis dan tersajinya data yang ada namun dalam hal pertanggungjawaban lemah. Jika ingin dikatakan Perbankan dalam keadaan sehat dan menjalankan aktivitasnya telah memenuhi standar operasional pekerjaan otomatis tidak akan menambah angka banyaknya pengaduan dan laporan masyarakat ke OJK. dalam Kurun waktu yang tidak cukup lama pihak OJK secara massif, terukur dan terjadwal telah menghadirkan sebuah metode sosialisasi dan demonstrasi menggaungkan konsep:

1. Literasi keuangan maksudnya ialah pengetahuan dan kecakapan untuk menerapkan pemahaman tentang konsep dan resiko, keterampilan agar dapat membuat keputusan yang efektif dalam konteks pembiayaan untuk meningkatkan kesejahteraan dalam mengelola keuangan, baik individu maupun sosial, dan dapat berpartisipasi dalam lingkungan masyarakat.

2. Inklusi keuangan merupakan suatu gagasan oleh OJK dan BI yang manfaatnya adalah pemenuhan hak setiap orang untuk memiliki akses dan layanan penuh dari lembaga keuangan secara tepat waktu, nyaman, informatif, dan terjangkau biayanya dengan penghormatan penuh kepada harkat dan martabatnya. layanan keuangan tersedia bagi seluruh segmen masyarakat dari berbagai daerah dan wilayah. inklusi keuangan ini secara berkesinambungan dan diharapkan dapat memberikan dampak positif terhadap kesejahteraan masyarakat melalui peningkatan pemahaman serta pemanfaatan produk dan jasa keuangan.

Dari pemaparan hal diatas penulis berpendapat bahwa keberadaan OJK ditengah-tengah kita telah memahami apa yang menjadi kekurangan dan kebutuhan yang paling penting untuk dilakukan, karena gagasan tersebut dilaksanakan dalam rangka memberi edukasi kepada masyarakat dan teknis pelaksanaannya pun dilakukan secara tepat pada sasaran yaitu menargetkan agar pesan-pesan ini tersampaikan dan turun langsung ke telinga masyarakat sebagai informasi penting tentang keuangan dan jenis pembiayaan yang sesuai kebutuhan pengelolaannya.

Tabel 1

Bank Umum dan Bank Perkreditan Rakyat yang diawasi oleh OJK Kota Makassar

\begin{tabular}{|c|c|c|}
\hline No. & $\begin{array}{c}\text { Jumlah Bank yang Diawasi } \\
\text { OJK Kota Makassar }\end{array}$ & \\
\hline 1. & $\begin{array}{l}\text { Jumlah Bank Umum yang diawasi Kantor } \\
\text { Regional } 6 \text { di wilayah Makassar }\end{array}$ & 21 \\
\hline 2. & $\begin{array}{l}\text { Jumlah BPR yang diawasi Kantor } \\
\text { Regional } 6 \text { di wilayah Makassar }\end{array}$ & 10 \\
\hline 3. & $\begin{array}{l}\text { Total Perbankan dalam pengawasan OJK } \\
\text { di Kota Makassar }\end{array}$ & 31 \\
\hline
\end{tabular}

Sumber: Hasil Wawancara Staff Perbankan OJK Makassar, 2020

Terdapat total 31 perbankan di Kota Makassar yang masih aktif menjalankan aktifitas perbankan. Bank Umum sebanyak 21, dan Bank Perkreditan Rakyat sebanyak 10.
Tabel 2

Daftar Perbankan yang diawasi oleh OJK Regional VI di Makassar

\begin{tabular}{|c|c|c|}
\hline No & Bank Umum & $\begin{array}{c}\text { Bank Perkreditan } \\
\text { Rakyat }\end{array}$ \\
\hline 1. & ABN Amro Bank NV & BPR Hasamitra \\
\hline 2. & Bank Arta Graha & BPR Niaga Madani \\
\hline 3. & Bank Bukopin & BPR Sulawesi Mandiri \\
\hline 4. & PT. Bank Central Asia. Tbk & BPR Batara Wajo \\
\hline 5. & $\begin{array}{l}\text { PT. Bank Danamon Indonesia. } \\
\text { Tbk }\end{array}$ & $\begin{array}{l}\text { BP Kota Tk II Ujung } \\
\text { Pandang }\end{array}$ \\
\hline 6. & PT. Bank Ekonomi & BPR Taruna Jujur Sakti \\
\hline 7. & $\begin{array}{l}\text { PT. Bank Internasional Indonesia. } \\
\text { Tbk }\end{array}$ & BPR Sulawesi Danajaya \\
\hline 8. & PT. Bank Lippo. Tbk & BPR Tabungan Rakyat \\
\hline 9. & PT. Bank Maspion Indonesia & $\begin{array}{l}\text { BPR Indotama UKM } \\
\text { Sulawesi }\end{array}$ \\
\hline 10. & PT. Bank Mayapada International & BPR Modern Makassar \\
\hline 11. & PT Bank Mandiri Tbk & - \\
\hline 12. & PT. Bank Mega. Tbk & - \\
\hline 13. & $\begin{array}{l}\text { PT. Bank Muamalat Indonesia. } \\
\text { Tbk }\end{array}$ & - \\
\hline 14. & PT. Bank Negara Indonesia Tbk & - \\
\hline 15. & PT. Bank Niaga Tbk & - \\
\hline 16. & PT. Bank Panin Tbk & - \\
\hline 17. & BPD Sulselbar & - \\
\hline 18. & PT. Bank Permata & - \\
\hline 19 & PT. Bank Rakyat Indonesia. Tbk & - \\
\hline 20 & PT. Bank Tabungan Negara & - \\
\hline 21 & PT. BTPN & - \\
\hline & Jumlah & 21 \\
\hline
\end{tabular}

Sumber: Hasil Wawancara Staff Perbankan OJK Makassar, 2020

Berdasarkan data pada Tabel 3 di atas dalam kurun waktu 2017 sampai dengan Mei 2020 ada beberapa bank yang berada dalam pengawasan dan pemeriksaan OJK. Dalam rapat antara OJK, Bank dan BPK ditemukan beberapa permasalahan yang berkaitan dengan pengendalian internal dan ketidakpatuhan bank terhadap ketentuan perundang-undangan.

Beragam masalah yang disoroti seperti pada tiap individu perbankan, mulai dari penggunaan fasilitas kredit modal kerja debitur, permasalahan hapus buku kredit, penetapan kelulusan penilaian kemampuan dan kepatuhan seorang direksi.

a. Keterbatasan Sumber Daya Manusia (SDM)

$>$ Jumlah Tenaga Profesional

Sebagai lembaga pengawas independen yang baru berdiri dan beroperasi di Indonesia, OJK diharapkan mampu membuat sektor jasa keuangan beroperasi lebih baik. Namun seperti yang telah dijelaskan sebelumnya, pembentukan dan pelaksanaan dari OJK akan membawa tantangan serta risiko. Pemerintah serta masyarakat Indonesia diharapkan dapat menangani risiko yang dimunculkan lembaga independen baru tersebut, dengan cara meninjau kembali aturan hukum maupun implementasi tugas dan fungsi dari OJK sebagai lembaga pengawas yang independen. Perlu diadakan proses seleksi dan pelatihan yang terpadu dalam pengoperasian 
OJK agar lembaga tersebut dapat didukung oleh sistem dan sumber daya manusia yang andal.

Diperlukan juga pelatihan-pelatihan sumber daya manusia pada sektor industri jasa keuangan agar dapat melahirkan para profesi manajemen risiko yang mampu mengatasi resiko-resiko yang muncul tidak hanya dari segi jumlah, kemampuan SDM menjadi tantangan tersendiri, OJK dituntut membangun sistem pengawasan yang terintegrasi menghadapi konglomerasi sektor jasa keuangan.

Dari segi jumlah tenaga kerja OJK yang ada perlu terus bertambah dan diharapkan mampu terampil dalam mendukung peningkatan stabilitas sistem keuangan agar dapat mengatur dan mengawasi industri keuangan secara individual, OJK juga menganalisis dan memantau potensi risiko sistemik dimasing-masing individual lembaga keuangan, sehingga memberi ruang bagi OJK untuk memantau secara lebih dalam berbagai kemungkinan resiko dan mengambil langkah-langkah mitigasinya.

Tabel 3

Jumlah Pengawas OJK dan Klasifikasi Pendidikan

\begin{tabular}{lllll}
\hline No. & Jenis & \multicolumn{2}{l}{ Klasifikasi } & Jumlah \\
& Kelamin & \multicolumn{2}{l}{ Pendidikan } & \\
\hline 1. & Laki - laki & S1 (Strata & 11 Orang \\
2. & Perempuan & 1 Orang \\
\hline Total & & 12 Orang & \\
\hline
\end{tabular}

Sumber: Hasil Wawancara Staff Pengawas Perbankan OJK Makassar, 2020

Jumlah pengawas OJK yang bertugas sebanyak 12 orang terdiri dari 11 orang pengawas laki-laki dan 1 orang pengawas perempuan. Dari tabel 5 diatas dapat diketahui bahwa keseluruhan pengawas OJK memiliki jenjang pendidikan S1.

Tabel 4

Tahapan Pendidikan OJK

\begin{tabular}{|c|c|c|c|}
\hline $\begin{array}{l}\text { Pendidikan } \\
\text { Kalsikal }\end{array}$ & $\begin{array}{l}\text { Pengenalan } \\
\text { OJK selama } 5 \\
\text { hari }\end{array}$ & $\begin{array}{l}\text { Kesamapt } \\
\text { aan } \\
\text { selama } 2 \\
\text { bulan }\end{array}$ & $\begin{array}{l}\text { Orientasi } \\
\text { kerja } \\
\text { selama } 8 \\
\text { bulan }\end{array}$ \\
\hline $\begin{array}{l}\text { On The Job } \\
\text { Training }\end{array}$ & $\begin{array}{l}\text { Pengenalan } \\
\text { satuan kerja } \\
\text { secara lebih } \\
\text { spesifik }\end{array}$ & $\begin{array}{l}\text { Kelompok } \\
\text { kerja }\end{array}$ & $\begin{array}{l}\text { Pelaksan } \\
\text { aan } 2 \\
\text { bulan }\end{array}$ \\
\hline Orientasi Keja & $\begin{array}{l}\text { Pendalaman } \\
\text { pemahaman } \\
\text { satuan kerja }\end{array}$ & Individu & $\begin{array}{l}\text { Pelaksan } \\
\text { aan } 8 \\
\text { bulan }\end{array}$ \\
\hline
\end{tabular}

Sumber: Hasil wawancara Ikbal Mudir, Kabag. Pengawas Perbankan

Langkah paling cepat mengatasi kekurangan orang adalah rekruitmen dari luar. Banyak pihak, dari lembaga jasa keuangan, akademisi dan lembaga negara, yang punya kapabilitas dan pengalaman mengenai pengelolaan lembaga jasa keuangan yang sangat dapat membantu. Mereka sebaiknya diajak bergabung melalui proses seleksi masuk terbuka.

$>$ Optimalisasi Pengembangan

OJK dihadapkan pada berbagai keterbatasan, baik keterbatasan infrastruktur kerja, jumlah sumber daya manusia maupun ketersediaan anggaran. Untuk mengatasi hal tersebut Anggota Dewan komisioner telah mengambil kebijakan umum diantaranya:
1. Optimalisasi Sumber Daya Manusia yang mempunyai potensi dan berpengalaman untuk ikut bersama Anggota Dewan Komisioner berpikir dan mencari jalan keluar atas permasalahan-permasalahan strategis yang dihadapi oleh OJK saat ini dan ke depan.

2. Memberikan kesempatan pegawai yang berpotensi untuk memiliki pengalaman dibidang yang baru dan belajar menghadapi berbagai masalah yang lebih kompleks.

3. Fine tune organisasi dan rotasi pegawai agar dapat mengoptimalkan penggunaan resources/sumber daya yang ada dan menciptakan proses keputusan yang lebih cepat dan kualitas hasil kerja yang dapat mengatasi permasalahan yang dihadapi. Rotasi ini merupakan salah satu strategi untuk memberikan tantangan bagi pegawai yang sudah cukup teruji di posisi tertentu dengan rata-rata sudah di posisi tersebut tiga tahun ke atas.

4. Re-focusing organisasi untuk memberikan fleksibilitas sehingga pegawai-pegawai yang memiliki potensi yang besar dan pengalaman yang luas untuk dapat ikut secara lebih fleksibel dalam mengaktualisasi dirinya dalam mencari terobosan atas berbagai tantangan OJK ke depan, yaitu dengan membentuk Strategic Committee \& Pusat Riset yang langsung bertanggung jawab kepada Anggota Dewan Komisioner.

OJK sebagai otoritas sektor jasa keuangan harus mampu merespon dinamika perubahan yang terjadi serta menjawab harapan pemerintah dan masyarakat agar OJK berperan lebih efektif dalam menjaga stabilitas sistem keuangan dan mendorong peran industri jasa keuangan dalam membiayai gerak roda pembangunan, meningkatkan kesejahteraan masyarakat dan menurunkan tingkat ketimpangan.

Tabel 5

Data Program Pengembangan SDM OJK yang Telah Mengikuti Program Pengembangan Tahun 2019

\begin{tabular}{|c|c|c|}
\hline No & Program Pengembangan SDM & $\begin{array}{r}\text { Jumlah } \\
\text { Pegawai }\end{array}$ \\
\hline 1 & $\begin{array}{ll}\text { Program } & \text { Pengembangan } \\
\text { Kepemimpinan } & \end{array}$ & 297 \\
\hline 2 & Program Pendidikan Formal & 24 \\
\hline 3 & Program On Boarding & 186 \\
\hline 4 & Program Purna Bakti & 46 \\
\hline 5 & Program Penugasan & 57 \\
\hline 6 & $\begin{array}{l}\text { Program } \quad \text { Pengembangan } \\
\text { Kompetensi }\end{array}$ & 2.691 \\
\hline 7 & $\begin{array}{lll}\text { Program } & \text { Sertifikasi } & \text { Jasa } \\
\text { Keuangan } & & \\
\end{array}$ & 199 \\
\hline \multicolumn{2}{|r|}{ Jumlah } & 3500 \\
\hline
\end{tabular}

Sumber : Hasil Wawancara Ikbal Mudir, Kabag. Pengawas Perbankan / Laporan Kinerja OJK 2019

\section{b. Ketersediaan Data yang Reliable}

Ketersediaan data ini adalah proses yang tidak bisa cepat karena pemahaman data membutuhkan waktu. Paling praktis adalah bekerjasama dengan Bank Indonesia sebagai pihak yang selama ini mengelola data tersebut. Perlu dilakukan kursus kilat/crash course mengenai bagaimana cara membaca 
dan menganalisa data-data lembaga keuangan tersebut. Tersedianya data memang ada dan sangat mampu untuk di analisis namun pertanggungjawaban untuk dapat diandalkan sebagai data yang akurat masih perlu pendalaman. Semenjak tahun 2017 OJK sudah melewati masa-masa kesulitan dalam hal data yang telah terintegrasi ke OJK dikarenakan proses pemindahan sebahagian karyawan Bank Indonesia ke Otoritas Jasa Keuangan yang sifatnya sukarela bukan paksaan.

Transisi di OJK akan menghadapi sebuah terobosan baru dengan lebih memaksimalkan tidak adanya masalah dalam hal data yang tersaji serta pengkinian data terus ditingkatkan. Terkait hal ini OJK hanya menguraikan tentang gambaran umum terkait data, tidak masuk kedalam intisari/isi dari datadata yang dimaksud, karena ini berkaitan dengan privasi lembaga dan adanya privasi pihak lain yang tidak bisa diekspos tanpa adanya permintaan resmi untuk kepentingan negara dan persetujuan dari Kepala Kantor OJK diketahui oleh Dewan Komisioner.

Ketersediaan data tersebut merujuk pada kondisi internal, memang menjadi tantangan paling besar bagi OJK adalah persiapan internal secara organisasi dan infrastruktur data pendukung untuk dapat menjalankan fungsi dan tanggungjawabnya. Keberhasilan OJK sejauh ini melakukan proses transisi yang relatif mulus dan tanpa gejolak, patut diappresiasi. Ini menunjukkan proses dan jajaran pimpinan di OJK sudah melakukan sesuatu yang benar, tinggal menjaga stabilitas dan perlunya peningkatan serta penguatan sistem. Dalam proses pengawasan dan pengaturan, data adalah hal yang amat kritikal. Bisa dibayangkan bagaimana proses pengawasan dan pengambil keputusan bisa dilakukan dengan baik, tanpa ketersediaan data yang memadai. Data menjadi basis pengambilan keputusan yang akurat dan tepat.

\section{KESIMPULAN DAN SARAN}

Berdasarkan hasil penelitian dapat disimpulkan bahwa pengawasan yang dilakukan OJK belum efektif, tidak mampu mengalami peningkatan jika hanya mengandalkan pola pemantauan dan kontrol pengawasan melalui sistem yang terintegrasi, diperlukan tenaga profesional yang berintegritas untuk secara berkala melakukan pemeriksaan langsung sesuai yang diatur dalam Undang-Undang Otoritas Jasa Keuangan Nomor 21 tahun 2011 Pasal 7, dalam upaya memberikan edukasi keuangan dan pemahaman resiko agar memberi dampak yang baik terhadap kegiatan usaha perbankan. Faktor penghambat dalam melakukan pengawasan aktivitas perbankan antara lain terbatasnya jumlah sumber daya manusia yang handal dalam bidang pemeriksaan langsung lembaga keuangan perbankan, pengembangan kualitas sumber daya manusia dalam bentuk pelatihan itu dilakukan secara kolektif dan nasional dan infrasturktur data dari lembaga pengawas sebelumnya ada namun tidak dapat diandalkan oleh OJK.

\section{DAFTAR PUSTAKA}

Ali, Achmad. 2009. Menguak Teori Hukum (Legal Theory) dan Teori Peradilan (Judicialprudence) Termasuk Interpretasi Undang-Undang (Legisprudence). Jakarta. Penerbit Kencana. Hal. 375

Djumhana, Muhammad. 2000. Hukum Perbankan di Indonesia. Bandung: Citra Aditya Bhakti.
Fuady, Munir. 1999. Hukum Perbankan Modern. Bandung: Citra Aditya Bakti.

Ghazali, Djoni S. dan Rachmadi Usman. 2010. Hukum Perbankan. Jakarta: Sinar Grafika.

Hartono, Sri Redjeki. 2001. Hukum Asuransi dan Perusahaan Asuransi. Jakarta: Sinar Grafika

Hermansyah. 2008. Hukum Perbankan Nasional Indonesia. Jakarta: Kencana Prenada Media Group

Imaniyati, Neni Sri. 2000. Hukum Perbankan dan Perbankan Syariah: Teori dan Praktik. Bandung: LPPM Unisba

Imaniyati, Neni Sri.2016. Pengantar Hukum Perbankan Indonesia. Bandung: PT Refika Aditama

Kadarisman, Muh. 2013. Manajemen Pengembangan Sumber Daya Manusia. Jakarta: Rajawali Pers.

Kasmir. 2014. Bank dan Lembaga Keuangan Lainnya. Edisi Revisi. Jakarta: Rajawali Pers

Makmur, 2011. Efektivitas Kebijakan Pengawasan Bandung: PT Refika Aditama.

Muhammad, Abdul Kadir. 1999. Hukum Perusahaan Indonesia. Bandung: Citra Aditya Bhakti.

Muhammad, Abdul Kadir 2004. Segi Hukum Lembaga Keuangan dan Pembiayaan. Bandung: Citra Aditya Bhakti

Mustaqim, Andika Hendra. 2010. Otoritas Jasa Keuangan Sebagai Solusi Sistem Ekonomi Nasional. Jakarta: Graha Ilmu.

Salim, H.S dan Erlis Septiana Nurbani, 2013. Penerapan Teori Hukum Pada Tesis dan Disertasi, Edisi PertamaCtk Kesatu, Jakarta: Rajawali Press.

Salman, Otje dan Anthon F Susanto. 2015. Teori Hukum, Bandung: PT. Refika Aditama

Simbolon, Maringan Masry. 2004. Dasar-Dasar Administrasi dan Manajemen, Jakarta: Ghalia Indonesia

Sinungan, Muchdarsyah. 1987. Uang dan Bank. Jakarta: Bina Aksara

Soekanto, Soerjono. 1985 Efektivitas Hukum dan Peranan Saksi, Bandung: Remaja Karya.

Sutendi, Adrian. 2014. Aspek Hukum Otoritas Jasa Keuangan. Jakarta: Raih Asa Sukses

Taneko, Soleman B. 1993 Pokok-Pokok Studi Hukum dalam Masyarakat, Jakarta: Rajawali Press.

Tobing, Raida L, dkk (Hasil Penelitian). 2011, Efektivitas Undang-Undang Moneey Loundering, Jakarta: Badan Pembinaan Hukum Nasional, Kementrian Hukum dan HAM RI.

Umam, Khatibul 2016. Perbankan Syariah. Dasar-Dasar dan Dinamika Perkembangannya di Indonesia. Jakarta. PT Raja Grafindo Persada.

Usman, Rachmadi. 2001. Aspek-Aspek Hukum Perbankan di Indonesia. Jakarta: Gramedia Pustaka Utama.

Wardiah, Mia Lasmi. 2017. Dasar-Dasar Perbankan. Bandung: CV Pustaka Setia

Bismar Nasution, Beberapa catatan Terhadap RUU Otoritas Jasa Keuangan, Buletin Hukum Perbankan dan Kebanksentralan, Volume 8, No. 3, September 2010.

Gultom, Miranda. 2005. Sambutan Deputi Gubernur Senior Bank Indonesia pada Seminar "Strategi Pengembangan Lembaga Keuangan Syariah di Indonesia". Jakarta: BI, 15 September 2005.

Heidi Mandanis Schooner, "Central Bank's Role in Bank Supervision in the United States and United Kingdom", Brooklyn International Law Journal, Year 2003. 
Wiwin Sri Haryani, 2011. Independensi Otoritas Jasa Keuangan dalam Perspektif Undang-Undang Nomor 21 Tahun 2011 tentang Otoritas Jasa Keuangan, Jurnal Legislasi Indonesia. Vol.9 No.3 Oktober 2012.

Zaidatul Amina, Kajian Pembentukan Otoritas Jasa Keuangan Di Indonesia: Melihat Dari Pengalaman Di Negara Lain, Universitas Negeri Surabaya, 2012.

Zulkarnain Sitompul, Kemungkinan Penerapan Universal Banking System di Indonesia: Kajian dari Perspektif Bank Syariah Jurnal Hukum Bisnis, Volume 20, Agustus-September 2002, hlm.4.

Agustina

Melani.

https://www.liputan6.com/bisnis/read/787799/plus-

minus-pengawasan-bank-oleh-ojk. diakses tanggal 30 Agustus 2019

CNBC Indonesia., OJK: Kebijakan Harus Berbasis Riset Komprehensif,

https://www.cnbcindonesia.com/news/20181014142911

-51-37304/ojk-kebijakan-harus-berbasis-risetkomprehensif, diakses pada 5 Agustus 2019

Dyah Ikhsanti. Otoritas Jasa Keuangan-Harapan Baru Ekonomi Indonesia. https://www.aturduit.com/articles/otoritas-jasakeuangan-harapan-baru-ekonomi-indonesia/ diakses February 18, 2014

Dosen Pendidikan, Efektivitas Adalah, https://www.dosenpendidikan.co.id/efektivitas-adalah/, diakses tanggal 25 November 2019

Maikel Jefriando, Kelahiran OJK Sejarah Baru Perekonomian Indonesia,

https://ekbis.sindonews.com/read/700589/90/kelahiranojk-sejarah-baru-perekonomian-indonesia-1356414181, diakses 1 Agustus 2019

Mughnifar Ilham, Pengawasan Menurut Para Ahli. https://materibelajar.co.id/pengawasan-menurut-paraahli/, diakses tanggal 25 November 2019

Otoritas Jasa Keuangan. FAQ https://www.ojk.go.id/id/Pages/FAQ-Otoritas-JasaKeuangan.aspx. di akses 05 Agustus 2019

Web.id Penulis, https://penulis.web.id/pengertian-otoritasjasa-keuangan-ojk.html, diakses 19 Agustus 2019

Undang-Undang Dasar Negara RI Tahun 1945 (pasca amandemen)

Undang-Undang Nomor 7 Tahun 1992 tentang Perbankan sebagaimana diubah dengan Undang-Undang Nomor 10 Tahun 1998 tentang Perbankan

Undang-Undang Nomor 3 Tahun 2004 tentang Bank Indonesia

Undang-Undang Nomor 21 Tahun 2011 tentang Otoritas Jasa Keuangan 